\title{
Standardization of Optimal Level of Coconut Variants in Chocolates Based on Consumer Acceptance
}

\author{
V. DIVYA ${ }^{1 *}$, D. BASKARAN ${ }^{2}$ and K.S.GNANALAKSSHMI ${ }^{3}$, \\ M. ABDUL REIINCLUDE ${ }^{3}$ and M. ABDUL REIYAS ${ }^{3}$ \\ 'Student (M.Tech), College of Food and Dairy Technology, TANUVAS, Chennai, India, 600052. \\ 2Dean, Faculty of Food Sciences, College of Food and Dairy Technology, \\ ${ }^{3}$ Assistant Professor, College of Food and Dairy Technology, TANUVAS, Chennai - 52, \\ TANUVAS, Chennai, India, 600052. \\ Corresponding author Email: divsarivan@gmail.com
}

http://dx.doi.org/10.12944/CRNFSJ.5.1.05

(Received: February 19, 2017; Accepted: March 22, 2017)

\begin{abstract}
A study was carried out to produce chocolates from coconut variants viz, coconut oil, coconut cream and coconut milk as a substitute for cocoa butter. The chocolate prepared with $40 \%$ cocoa butter was taken as control. The preliminary trials were conducted with different composition of ingredients for the optimization of the level of substitution of coconut variants. Cocoa butter substituted at the levels of $10 \%$, $20 \%$ and $30 \%$ by coconut oil, coconut cream and coconut milk respectively were optimized based on the consumer acceptance. The raw materials used in the fabrication of chocolate were subjected to analysed for Peroxide value (PV), Acid Value (AV) and Free Fatty Acid (FFA) content and were found to have desirable oxidative stability.
\end{abstract}

Keywords: Cocoa Butter; Coconut Oil; Coconut Cream; Coconut Milk; Optimization: Consumer acceptance; oxidative stability

\section{INTRODUCTION}

The chocolate industry in India is one of the major segments of the Indian confectionery, which is at the pace of increasing demand. Food retail industry and confectionery are the fastest growing sectors which would accelerate the growth of chocolates in the country. Dark chocolate which has only $9 \%$ market share at present is expected to be the fastest growing segment owing to the numerous health benefits and increasing awareness among Indian consumers. Dark chocolates are found to be rich in antioxidants such as flavonoids, epicatechin, catechin and procyanidins than in milk and other chocolates. The daily consumption of dark chocolate is believed to prevent or delay metabolic diseases, including cardiac disease ${ }^{1}$.
The popularity of chocolate appears to be mainly owing to its potential to arouse sensory perception and positive emotions ${ }^{2}$. Chocolate is perceived as a comfort food which provides sense of goodness during depressive moods ${ }^{3}$. Cocoa butter is an important ingredient for chocolate making and is used as the continuous phase in chocolate that support the non-fat ingredients ${ }^{4}$ and is responsible for much of the snap, gloss, appearance, mouth feel and flavour release typical for chocolates. Due to the limited supply and the high demand, the price is high and can fluctuate in time depending on the crop yield ${ }^{4}$. Hence alternatives to cocoa butter can be used which would fulfil the demands of cocoa butter fat and reduce the cost of production. Alternatives to cocoa butter have been developed by food researchers. Cocoa butter alternatives can 
be classified into three groups: (1) Cocoa butter substitutes (2) Cocoa butter replacers and (3) Cocoa butter equivalents. The alternatives of cocoa butter developed so far could not meet the exact demand of cocoa butter. Hence it is necessary to conduct further research on this subject to discover the alternatives to cocoa butter fat that could be able to fulfil the demands of cocoa butter fat.

Coconut is one of the ancient food ingots in nature from the time immemorial, especially within Asian cuisine. Botanically, the coconut palm is a monocotyledon and belongs to the order Arecaceae, family Palmae and the species is known as Cocus nucifera Linn. It is promoted as a dietary supplement said to optimize health ${ }^{5}$. The supply and interest in coconut consumption has increased during the last few years. It is from the flesh, coconut fat is extracted $^{6}$. Coconut fat consists mainly about $90 \%$ of saturated fatty acids. The major fatty acids present in coconut fat are lauric acid (12:0) with 46\%, myristic acid (14:0) with $17 \%$ and palmitic acid (16:0) with $9 \%^{7}$ and is also totally devoid of trans-fatty acids which are now thought to be more harmful than saturated fatty acids ${ }^{8}$.

The food processing sector has not paid due attention to diversification and value addition to coconut, coconut products and by products. The introduction of medicinal and organic ingredients in the manufacturing of chocolates will lead to a new trend and advancement in the traditional food disciples ${ }^{9}$. The present work has been proposed with the main objective of producing low cost coconut substituted cocoa base chocolate prototypes without compromising on its sensory attributes with partial replacement of premium priced cocoa butter using coconut fats viz., coconut oil, coconut cream and coconut milk. This attempt would also favour the coconut farmers in regaining the remunerative prices for coconut due to rise in demand for coconut base material as well as chocolate novelties that are developed during the present research protocol.

\section{MATERIALS AND METHODS \\ Cocoa butter}

Cocoa butter is the chief ingredient in chocolate making which contains $36-43 \%$ of unsaturated fat $(29-43 \%$ is MUFA, $0-5 \%$ is PUFA).
Commercially available cocoa butter was used. Cocoa powder. Cocoa powder containing about $12 \%$ fat, $57 \%$ carbohydrates, $19.6 \%$ protein and $33.2 \%$ fibre obtained from commercially available brand in the market was used for the study. Cocoa powder was added at the level of $20 \%$ to the developed chocolates.

\section{Icing sugar}

Commercially available good quality icing sugar was used. Standard inclusion level of $40 \%$ of icing sugar was maintained for developed chocolates.

\section{Lecithin}

Lecithin was used as the viscosity modulator in the preparation of chocolate. $0.5 \%$ of soy lecithin was added in each variety of chocolate.

\section{Coconut variants}

Cold pressed virgin coconut oil (Lauric acid - 53\%, Palmitic acid - 8.5\%, Oleic acid$2.5 \%)$ obtained from private firm was used for the preparation of chocolates. Coconut cream (95\% of coconut extract, fat $-29 \%$ of which $90 \%$ is saturated) and Coconut milk ( $85 \%$ of coconut extract, fat - $25 \%$ of which $75 \%$ is saturated) obtained from nearby market was used for the preparation of chocolates.

\section{EXPERIMENTAL DESIGN}

The different percentages of cocoa butter and coconut variants viz., coconut oil, coconut cream and coconut milk were formulated and chocolates were prepared with different percentage of substitution levels. The chocolate taken as control was prepared with $40 \%$ cocoa butter, $40 \%$ sugar and $20 \%$ cocoa powder. The cocoa butter was substituted up to the level of $40 \%$ with coconut oil, coconut milk and coconut cream, beyond which there was increase in viscosity of the chocolate mix which made moulding and demoulding of chocolates difficult. The chocolates were prepared following the steps given in Figure-1. The highly accepted chocolate formulation derived using taste panel consisting of six untrained panelists was selected and optimised. The remaining blends were rejected because the increased amount of coconut cream and coconut milk showed increase in viscosity and poor crystallisation. 


\section{Treatments}

- Control-Chocolate was prepared with cocoa butter (40\%).

- $\mathbf{C O}_{10 \%-40 \%}$-Chocolates were prepared by substituting cocoa butter (40\%) with $10 \%$ to $40 \%$ of coconut oil.

- $\quad$ C C $_{10 \%-40 \%}$-Chocolate was prepared by substituting cocoa butter (40\%) with $10 \%$ to $40 \%$ of coconut cream.

- $\quad \mathbf{C M}_{10 \%-30 \%}$-Chocolate was prepared by substituting cocoa butter (40\%) with $10 \%$ to $30 \%$ of coconut milk.

\section{Analysis of oxidative stability}

The Peroxide value (PV), Free Fatty Acid (FFA) content and Acid Value (AV) of cocoa butter (CB), coconut oil (CO), coconut cream (CC) and coconut milk (CM) employed in the production of chocolate were estimated by following the standard procedures of AOAC, $2000^{10}$.

\section{Sensory evaluation}

The Hedonic Scale Test, developed in 1947 at the Quartermaster Food and Container Institute for the Armed Forces, defines the psychological attitudes of "like" or "dislike" in a linear scale. In this type of sensory analysis the chocolate was assessed in 9 point scale. Numerical values ranging from 1 (dislike extremely) to 9 (like extremely) were calculated and mean values were used. This test is the most popular one for preference evaluation of food products.

\section{Statistical analysis}

The data obtained were analysed statistically by applying one way ANOVA in SPSS software (version 20.0) as per the standard procedure of Snedecor and Cochran, 1994.

\section{RESULTS AND DISCUSSIONS}

Analysis of Ingredients of chocolate for determination of oxidative stability

\section{Peroxide value}

From Table-1 the Peroxide value of cocoa butter was estimated to contain higher limit of 1.09, which was found to be significantly differing from the

\section{FLOW CHART FOR PREPARATION OF CHOCOLATE}

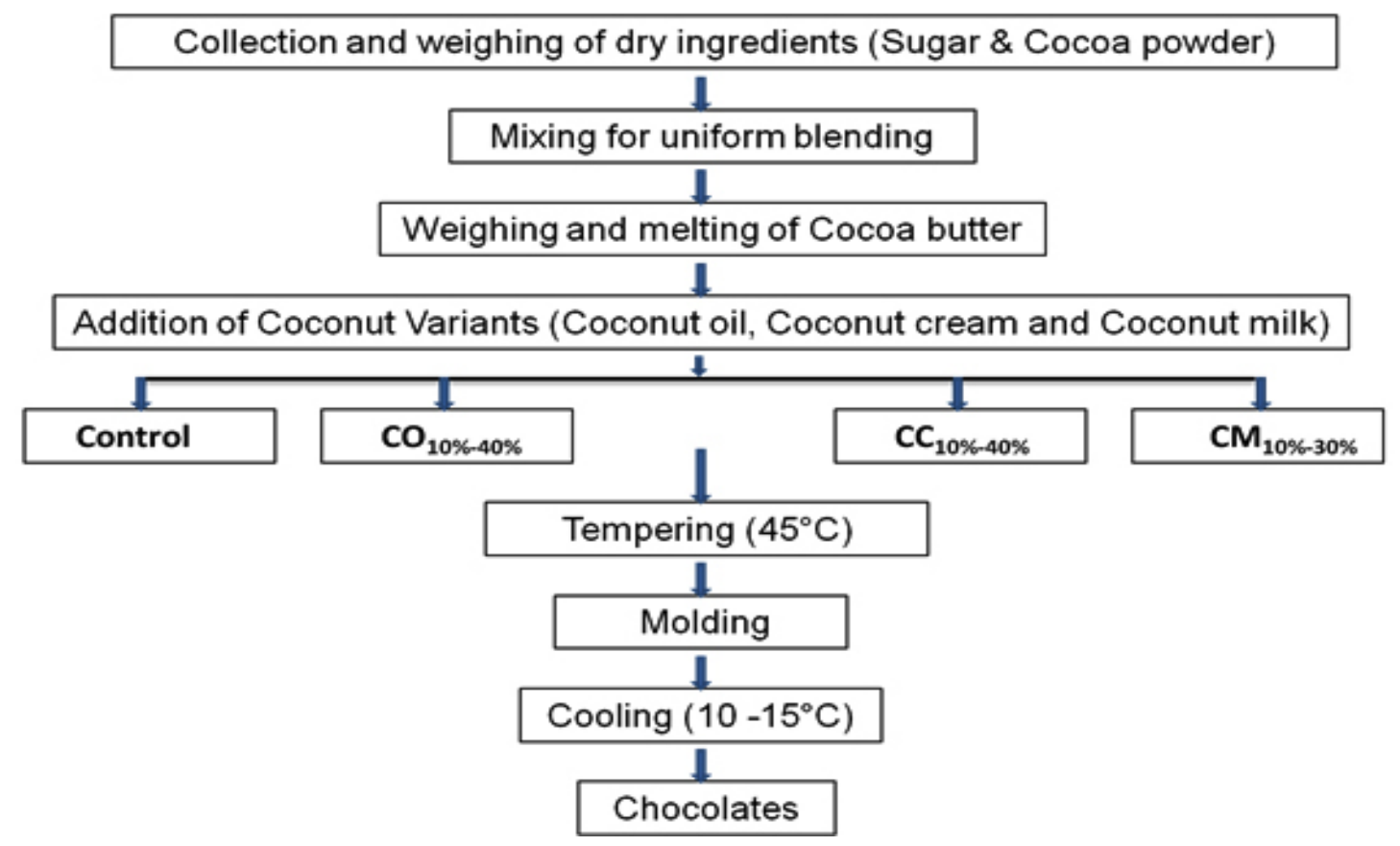

Fig. 1: Flow chart for preparation of chocolates 
coconut variants utilized in the substitution of cocoa butter. Amongst the coconut variants, Peroxide Value was estimated to have markedly lesser value of 0.39 meq. $\mathrm{O}_{2} / \mathrm{kg}$ for coconut oil followed by coconut cream and coconut milk with 0.76 and 0.84 meq. $\mathrm{O}_{2} / \mathrm{kg}$ respectively. The study revealed that coconut variants were subjected to the minimal level of oxidative changes than the control cocoa butter used in the fabrication of chocolate, which has provided valid information on the suitability of the coconut variants for the substitution in the chocolate base. The results obtained were in agreement with the results of Clercq and Dewettinck (2012) ${ }^{11}$ who studied the cocoa butter from various regions and the peroxide value was estimated to be in the range of 0.85 to 4.31 meq. $\mathrm{O}_{2} / \mathrm{kg}$. The materials used for the current study was found to be highly stable in conformity with the findings observed by Moigradean $(2012)^{12}$. that a product with peroxide value between 1 and 5,5 and 10 , and above 10 meq. $\mathrm{O}_{2} / \mathrm{kg}$ were classified respectively as minimally oxidative, moderately oxidative and highly oxidative.

\section{Free Fatty Acid content}

In Table-1, the fatty acid content of cocoa butter and coconut variants were found to be in the range of 0.13 to $1.33 \%$. The coconut oil used in the study had a very low value of free fatty acid content below $0.5 \%$ implying the fact that it has undergone very less oxidative changes. The free fatty acid content of coconut oil was well within the limits as prescribed in $\mathrm{APCC}^{13}$ (Asian and Pacific Coconut Community, 2003) standards to be not more than $0.5 \%$ for virgin coconut oil. As per codex standards ${ }^{14}$ (2008) the free fatty acid content of cocoa butter should not exceed $1.75 \%$ and the present study showed significantly lower values than the maximum limits. The free fatty acid content of coconut oil used correlated with the study of Dayrit et al. (2007) $)^{15}$ which was in the range of $0.13 \%$ to $0.43 \%$. Thus all the ingredients used had good oxidative stability and their oxidative values were within the prescribed standards.

\section{Acid Value}

From Table- 1 the acid value was estimated to be high for cocoa butter which differed significantly ( $P$ d" 0.01) from the coconut variants utilized in the substitution of cocoa butter. Though cocoa butter had predominantly high acid value, the flavour defects were not appreciable in Taste panel evaluation. Among the coconut variants utilized for the study,

Table 1: Estimation of Peroxide Value (PV), Free Fatty Acid (FFA) and Acid Value (AV) of Cocoa butter and Coconut variants for the determination of oxidative stability (Mean \pm SE)@

\begin{tabular}{lcccc}
\hline Ingredients & $\begin{array}{c}\text { Moisture } \\
\%\end{array}$ & $\begin{array}{c}\text { PV } \\
\text { meq.peroxide/Kg }\end{array}$ & $\begin{array}{c}\text { FFA } \\
\%\end{array}$ & $\begin{array}{c}\text { AV } \\
\text { mg KOH/g }\end{array}$ \\
\hline Cocoa butter & 1.00 & $1.09 \pm 0.020 \mathrm{~d}$ & $1.03 \pm 0.012 \mathrm{~d}$ & $2.04 \pm 0.023 \mathrm{~d}$ \\
Coconut oil & 1.00 & $0.39 \pm 0.017 \mathrm{a}$ & $0.13 \pm 0.009 \mathrm{a}$ & $0.26 \pm 0.018 \mathrm{a}$ \\
Coconut cream & 65.00 & $0.76 \pm 0.012 \mathrm{~b}$ & $0.33 \pm 0.012 \mathrm{~b}$ & $0.66 \pm 0.024 \mathrm{~b}$ \\
Coconut milk & 72.50 & $0.84 \pm 0.023 \mathrm{c}$ & $0.43 \pm 0.012 \mathrm{c}$ & $0.84 \pm 0.024 \mathrm{c}$ \\
& F value & $157.04^{* *}$ & $759.04^{\star *}$ & $1005.96^{* *}$ \\
\hline
\end{tabular}

Table 2: Optimisation of substitution level of coconut oil in chocolate base derived using taste panel (Mean \pm SE) @

\begin{tabular}{lcccccc}
\hline Parameters & Control & $\mathrm{CO}_{10 \%}$ & $\mathrm{CO}_{20 \%}$ & $\mathrm{CO}_{30 \%}$ & $\mathrm{CO}_{40 \%}$ & F Value \\
\hline Color & $8.46 \pm 0.021$ & $8.43 \pm 0.032$ & $8.42 \pm 0.018$ & $8.44 \pm 0.027$ & $8.45 \pm 0.022$ & $\mathrm{NS}$ \\
Flavour & $8.28 \pm 0.030^{\mathrm{c}}$ & $8.33 \pm 0.033^{\mathrm{c}}$ & $8.13 \pm 0.033^{\mathrm{b}}$ & $8.10 \pm 0.036^{\mathrm{b}}$ & $7.96 \pm 0.033^{\mathrm{a}}$ & $19.356^{\star \star}$ \\
Texture & $8.58 \pm 0.030^{\mathrm{b}}$ & $8.43 \pm 0.032^{\mathrm{b}}$ & $8.14 \pm 0.034^{\mathrm{a}}$ & $8.13 \pm 0.046^{\mathrm{a}}$ & $8.15 \pm 0.042^{\mathrm{a}}$ & $13.455^{\star \star}$ \\
Appearance & $8.55 \pm 0.034^{\mathrm{c}}$ & $8.45 \pm 0.025^{\mathrm{c}}$ & $8.10 \pm 0.036^{\mathrm{b}}$ & $7.98 \pm 0.030^{\mathrm{a}}$ & $7.96 \pm 0.028^{\mathrm{a}}$ & $66.930^{\star *}$ \\
Overall & $8.51 \pm 0.030^{\mathrm{c}}$ & $8.41 \pm 0.030^{\mathrm{c}}$ & $8.15 \pm 0.022^{\mathrm{b}}$ & $8.03 \pm 0.055^{\mathrm{a}}$ & $7.96 \pm 0.021^{\mathrm{a}}$ & $52.967^{\star \star}$ \\
Acceptability & & & & & & \\
\hline
\end{tabular}


coconut oil was found to have the lowest acid value followed by coconut cream and coconut milk. The high amount of acid value in coconut cream and coconut milk when compared to coconut oil can be attributed to the presence of moisture which had an impact on the oxidative stability of the sample. The lesser acid value of the coconut variants implies their suitability to produce highly stable final products. The results obtained were agreeable with the findings observed by Depypere et al. (2009) ${ }^{16}$ which was between 1.54 and $3.05 \mathrm{mg} \mathrm{KOH} / \mathrm{g}$. In the present study, the acid values of samples were between 0.26 and $2.04 \mathrm{mg} \mathrm{KOH} / \mathrm{g}$.

Optimisation of Coconut substitutes in Chocolate base. Optimisation of substitution level of coconut oil in chocolate base derived using taste panel

The sensory scores obtained for colour of chocolates substituted with different levels of coconut oil viz., $10 \%, 20 \%, 30 \%$ and $40 \%$ given in Table-2 were found to be similar to the control and there was no significant difference ( $P$ d" 0.01) between treatments in the study. The results were in concomitance to the study conducted by Melo et al. $(2009)^{17}$ which reported that the sensory attributes did not exhibit marked changes for the newer chocolate variants in the development of diabetic chocolates.

Optimisation of substitution level of coconut oil in chocolate base derived using taste panel. Table-2 indicates that the attributes of flavour, texture, appearance and overall acceptability were found to be highly significant ( $P$ d" 0.01 ) between the treatments of different levels of substitution with coconut oil viz., $10 \%, 20 \%, 30 \%$ and $40 \%$. The scores gave encouraging results that there was no significant difference within the treatments between the control and chocolate substituted with $10 \%$ coconut oil. The sensory scores for flavour of chocolate substituted with coconut oil at $10 \%$ showed higher values than even the control which was found to be highly acceptable among the taste panel. The scores for overall acceptability of chocolate substituted with coconut oil at $10 \%$ were in cognizance to the control and hence $10 \%$ coconut oil substitution level was optimized to be superior on all aspects of the parameters under consideration.

The results obtained in the present study were found to be in agreement with the studies conducted by El-kalyoubi (2011) ${ }^{18}$ which indicated that the lower replacement rate of fat was close to control sample and increasing the ratio of fat replacer affected the rheological properties of chocolate.

\section{Optimisation of substitution level of coconut cream in chocolate base derived using taste panel}

The sensory scores for colour of chocolates substituted with different levels of coconut cream viz., $10 \%, 20 \%, 30 \%$ and $40 \%$ from Table-3 indicated that there was no significant difference $(P>0.05)$ in the scores obtained between the control and treatments.

The sensory parameters of flavour, texture, appearance and overall acceptability given in Table-3 were found to be highly significant ( $P$ d" 0.01) between the treatments at the substitution levels viz., $10 \%, 20 \%, 30 \%$ and $40 \%$ with coconut cream and no significant difference was observed between the control and chocolate substituted with $20 \%$ coconut

Table 3: Optimisation of substitution level of coconut cream in chocolate base derived using taste panel (Mean \pm SE) @

\begin{tabular}{|c|c|c|c|c|c|c|}
\hline Parameters & Control & $\mathrm{CC}_{10 \%}$ & $\mathrm{CC}_{20 \%}$ & $\mathrm{CC}_{30 \%}$ & $\mathrm{CC}_{40 \%}$ & F Value \\
\hline Color & $8.43 \pm 0.021$ & $8.41 \pm 0.032$ & $8.42 \pm 0.027$ & $8.42 \pm 0.028$ & $8.43 \pm 0.031$ & NS \\
\hline Flavour & $8.58 \pm 0.032^{c}$ & $8.01 \pm 0.034^{b}$ & $8.59 \pm 0.031^{c}$ & $8.10 \pm 0.037^{b}$ & $7.68 \pm 0.070^{a}$ & $64.909^{\star *}$ \\
\hline Texture & $8.58 \pm 0.031^{c}$ & $8.11 \pm 0.035^{b}$ & $8.43 \pm 0.042^{c}$ & $8.01 \pm 0.033^{b}$ & $7.45 \pm 0.043^{a}$ & $180.345^{\text {** }}$ \\
\hline Appearance & $8.55 \pm 0.034^{d}$ & $8.28 \pm 0.031^{c}$ & $8.52 \pm 0.022^{d}$ & $7.93 \pm 0.043^{b}$ & $7.56 \pm 0.033^{a}$ & $160.550^{* *}$ \\
\hline $\begin{array}{l}\text { Overall } \\
\text { Acceptability }\end{array}$ & $8.51 \pm 0.031^{d}$ & $8.28 \pm 0.041^{c}$ & $8.45 \pm 0.026^{d}$ & $8.02 \pm 0.022^{b}$ & $7.51 \pm 0.032^{a}$ & $185.32^{* *}$ \\
\hline
\end{tabular}


Table 4: Optimisation of substitution level of Coconut milk in chocolate base derived using taste panel (Mean \pm SE) @ Parameters

\begin{tabular}{lccccc}
\hline & Control & $\mathbf{C M}_{10 \%}$ & $\mathbf{C M}_{20 \%}$ & $\mathbf{C M}_{30 \%}$ & F Value \\
\hline Color & $8.42 \pm 0.032$ & $8.41 \pm 0.025$ & $8.41 \pm 0.028$ & $8.42 \pm 0.031$ & NS \\
Flavour & $8.52 \pm 0.033^{\mathrm{d}}$ & $8.06 \pm 0.035^{\mathrm{a}}$ & $8.20 \pm 0.032^{\mathrm{b}}$ & $8.31 \pm 0.030^{\mathrm{c}}$ & $37.78^{\star \star}$ \\
Texture & $8.58 \pm 0.032^{\mathrm{d}}$ & $8.21 \pm 0.030^{\mathrm{b}}$ & $8.06 \pm 0.034^{\mathrm{a}}$ & $8.32 \pm 0.042^{\mathrm{c}}$ & $47.01^{\star \star}$ \\
Appearance & $8.55 \pm 0.034^{\mathrm{d}}$ & $8.18 \pm 0.031^{\mathrm{b}}$ & $7.95 \pm 0.043^{\mathrm{a}}$ & $8.45 \pm 0.032^{\mathrm{c}}$ & $31.20^{\star \star}$ \\
Overall & $8.51 \pm 0.031^{\mathrm{d}}$ & $8.28 \pm 0.037^{\mathrm{b}}$ & $8.06 \pm 0.032^{\mathrm{a}}$ & $8.38 \pm 0.022^{\mathrm{c}}$ & $22.22^{\star \star}$ \\
Acceptability & & & & & \\
\hline
\end{tabular}

@ - Average of six trials (Different superscripts in a row differ significantly)

** - Highly Significant $(P \leq 0.01)$

NS- Non significant $(P>0.05)$

CO10\%-40\%-- Subscript indicates level of substitution of coconut oil

CC10\%-40\%-- Subscript indicates level of substitution of coconut cream

CM10\%-30\%-- Subscript indicates level of substitution of coconut milk

cream within the treatments. The sensory scores for flavour, appearance and overall acceptability of chocolate substituted with coconut cream at $20 \%$ level was found to be higher than at 10\%, 30\% and $40 \%$ levels and thus $20 \%$ substitution level of coconut cream was optimized which had highest acceptability.

The present findings were found to be in accordance with the research findings observed by Barnett (1978) ${ }^{19}$ that fat substituted at higher level increased the viscosity of chocolate mix which made the demoulding of chocolate impossible.

Optimisation of substitution level of coconut milk in chocolate base derived using taste panel

The sensory scores given in Table-4 obtained for the colour of the control and chocolates substituted with different levels of coconut milk viz., $10 \%, 20 \%$ and $30 \%$ showed that there existed no significant difference $(P>0.05)$ between treatments which revealed that the level of substitutions did not influence the colour of the chocolates. The attributes of flavour, texture, appearance and overall acceptability from Table-4 showed highly significant difference ( $P$ d" 0.01) between the control and the treatments at different substitution levels of coconut milk viz., $10 \%, 20 \%$ and $30 \%$. The scores for these parameters revealed that chocolate made with the substitution of $30 \%$ coconut milk was found to have scored the highest among the different levels of substitution and its scores were equivalent to the control with no significant difference. Hence, chocolate prepared with $30 \%$ level of substitution was selected and optimized. The findings by Olu et al. $(2013)^{20}$ disclosed that coconut milk at $30 \%$ substitution showed the peak acceptability which was in agreement to the present study. The results of the current study concurred with the findings recorded by Farooqui et al. (2014) ${ }^{21}$ who has studied the changes in sensory parameters of chocolate prepared using coconut milk.

\section{CONCLUSION}

The coconut processing industry remains confined to only copra production, oil extraction and coir products. The present work would favour the coconut farmers in regaining the remunerative prices for coconut due to rise in demand for coconut base material as well as the developed chocolate novelties with different levels of substitution of cocoa butter with coconut oil (10\%), coconut cream (20\%) and coconut milk (30\%).

\section{ACKNOWLEDGEMENT}

We kindly acknowledge the help rendered by College of Food and Dairy Technology and CAMPCO chocolate factory for carrying out the analysis. 


\section{REFERENCES}

1. Zomer E, Owen A, Magliano D. J, Liew D and Reid C. M. The effectiveness and cost effectiveness of dark chocolate consumption as prevention therapy in people at high risk of cardiovascular disease: best case scenario analysis using a Markov model. British Medical Journal: 344: 3657 (2012).

2.. $\quad$ Macht $M$ and Dettmer, D. Everyday mood and emotions after eating a chocolate bar or an apple. Appetite: 46: 332-336: (2006).

3. Macdiarmid J. I and Hetherington M. M. 1995. Mood modulation by food: an exploration of affect and cravings in "chocolate addicts". British Journal of Clinical Psychology:34 : 129-138: (1995).

4. Smith K.W. Cocoa butter and cocoa butter equivalents. In: Gunstone, F, editor. Structured and modified lipids. Bedfordshire, Unilever Research Colworth. p 401-422: (2001).

5. Paz D. C, Jimeno C, Sy R, Punzalan F. E and Pena P. D. The effect of virgin coconut oil on lipid profile and fasting blood sugar: A phase I clinical trial. Phillippine Journal of Internal Medicine: 48(2) : 1-6: (2010).

6. Jonsson L, Marklinder I, Nydahl M and Nylander A. Department of Food Science. Sweden; p. 197: (2008).

7. Abrahamsson L, Andersson A, Becker W and Nilsson G. Department of Food, Nutrition and Dietetics. Sweden: p. 116. (2008).

8. Amarasiri W. A. and Dissanayake A. S. Coconut fats. The Ceylon medical journal: 51(2) : 47-51: (2006).

9. Shrestha T. Demand for dark chocolate to drive India's chocolate industry: (2014).

10. AOAC. Official methods of analysis, $18^{\text {th }}$ Edition, Washington DC: (2000).

11. Clercq D. N. and Dewettinck K. Changing the functionality of cocoa butter. Agriculture and Food Sciences: XIV, 1 - 220: (2011).

12. Moigradean $D$, Mariana-Atenaand $P$, Gogoasa I. 2012. Quality characteristics and oxidative stability of coconut oil during storage. Journal of Agroalimentary Processes and Technologies: 18(4) :272-276: (2012).
13. Dayrit F. M, Buenafe O. E. M, Chainani E. T, Vera I. M. S. D, Dimzon I. K. D, Gonzales E. $G$ and Santos J. E. R. 2007. Standards for essential composition and quality factors of commercial virgin coconut oil and its differentiation from RBD coconut oil and copra oil. Philippine Journal of Science: 136(2) : 119-129: (2007).

14. Asian and Pacific Coconut Community (APCC). Standards for virgin coconut oil: (2003).

15. Codex Alimentarius Commission: Codex Standard for Named Vegetable Oils, Codex Stan 210. Joint FAO/WHO Food Standards Programme, Sept 2008.

16. F. Depypere N, de Clercq M, Segers B, Lewille and Dewettinck K. Triacylglycerol migration and bloom in filled chocolates: effects of low-temperature storage. European Journal of Lipid Science and Technology: 111(3) : 280-289: (2009).

17. Melo, L. L. M. M. D, Bolini H. M. A. and Efraim P. Sensory profile, acceptability, and their relationship for diabetic/reduced calorie chocolates. Food Quality and Preference: 20(2) : 138-143: (2009).

18. El-Kalyoubi M, Khallaf M. F, Abdelrashid A and Mostafa E. M. Quality characteristics of chocolate - Containing some fat replacer. Annals of Agricultural Sciences: 56(2) : 89-96: (2011).

19. Barnett C. D. Raw materials. In: The art and science of candy manufacturing. Books for Industry, Division of Magazines, NewYork, $p$ 1: (1978).

20. Olu, M, Ogunmoyela O. A. B, Oluwajob S. O, Jimoh O, Adekoyeni O. O and Dania O. 2013. Effect of coconut milk substitution on the nutrient and sensory properties of malted and unmalted sorghum ogi. Academic Research International: 4(1): 372: (2013).

21. Farooqui, M. U, Raheem M. I. A and Masih D. 2014. Development and Quality Evaluation of Coconut Milk Chocolate By Incorporation of Fat and Corn Flour. International Journal of Scientific Research: 3(8): (2014). 